\title{
Surveillance of intradomiciliary contacts of leprosy cases: perspective of the client in a hyperendemic municipality
}

\author{
Vigilância de contatos intradomiciliares de hanseníase: perspectiva do usuário em município hiperendêmico
}

Vigilancia de contactos intradomiciliarias de lepra: perspectiva del usuario en municipio hiper endémico

\section{Helizandra Simoneti Bianchini Romanholo', Eliana Amorim de Souzall,III, Alberto Novaes Ramos Júnior", Adélia Cileode Gomes Castelo Branco Kaiser ${ }^{\text {IV }}$, Ismália Oliveira da Silvav", Aline Lima Brito", Cídia Vasconcellos ${ }^{\mathrm{I}, \mathrm{VI}}$}

IInstituto de Assistência Médica ao Servidor Público Estadual de São Paulo / Universidade Cidade de São Paulo, Postgraduate Program in Health Sciences. São Paulo, Brazil.

"Universidade Federal do Ceará, Medical school, Postgraduate Program in Public Health. Fortaleza, Ceará, Brazil.

"I' Universidade Federal da Bahia, Interdisciplinary Institute of Health Anísio Teixeira, Medicine Course.

Vitória da Conquista, Bahia, Brazil.

IV Governo do Estado de Rondônia, Regional Hospital of Cacoal. Cacoal, Rondônia, Brazil.

${ }^{\vee}$ Faculdade de Ciências Biomédicas de Cacoal, Bachelor's Degree in Medicine. Cacoal, Rondônia, Brazil.

${ }^{V}$ Universidade São Paulo, Medical school. São Paulo, Brazil.

How to cite this article:

Romanholo HSB, Souza EA, Ramos Jr AN, Kaiser ACGCB, Silva IO, Brito AL, et al. Surveillance of intradomiciliary contacts of leprosy cases: perspective of the client in a hyperendemic municipality.

Rev Bras Enferm [Internet]. 2018;71(1):163-9. DOI: http://dx.doi.org/10.1590/0034-7167-2016-0607

Submission: 12-20-2016

Approval: 03-31-2017

\begin{abstract}
Objective: To characterize approach methods for intradomiciliary contacts (IdC) of leprosy cases resident in Northern Brazil, during 2001-2012. Method: A cross-sectional and descriptive study in the state of Rondônia. Included IdC of leprosy cases diagnosed/ reported in SINAN-Ministry of Health (MS), 2001-2012. A semi-structured instrument was applied to the IdCs, with six interventions: complete dermatological examination; complete neurological examination; BCG vaccination; instructions for return to the health unit; BCG guidance; and guidance to mobilize other contacts. Results: From a total of 459 IdCs included, failure to perform the dermatological examination was reported by 191 people (41.6\%) and the neurological examination, by 252 (54.9\%); 138 (30.1\%) did not have BCG indicated and 122 (26.6\%) did not receive guidelines; 257 (56.0\%) were not advised to return for a new evaluation/follow-up and 186 (40.5\%) were not asked to mobilize other contacts. Conclusion: Despite the favorable indicators of IdC examination coverage in the state, the evaluation process presents patterns that indicate operational quality failures.

Descriptors: Leprosy; Surveillance; Communicant Search; Prevention \& Control; Epidemiology.
\end{abstract}

\section{RESUMO}

Objetivo: Caracterizar padrões de abordagem de contatos intradomiciliares (Cld) de casos de hanseníase residentes no Norte do Brasil, de 2001-2012. Método: Estudo transversal e descritivo no estado de Rondônia. Incluídos Cld de casos de hanseníase diagnosticados/ notificados no SINAN-Ministério da Saúde (MS), 2001-2012. Aplicou-se instrumento semiestruturado aos Cld verificando-se seis intervenções: exame dermatológico completo; exame neurológico completo; vacinação BCG; orientação para retorno à unidade de saúde; orientação sobre BCG e orientação para mobilizar outros contatos. Resultados: Foram incluídos 459 Cld. A não realização do exame dermatológico foi referida por 191 pessoas (41,6\%) e o neurológico, por 252 (54,9\%); 138 (30,1\%) não tiveram a BCG indicada e 122 (26,6\%) não receberam orientações; 257 (56,0\%) não foram orientados a retornar para nova avaliação/seguimento e $186(40,5 \%)$ não foram orientados para mobilização de outros contatos. Conclusão: Apesar dos indicadores favoráveis de cobertura de exame de Cld no estado, o processo de avaliação apresenta padrões que indicam falhas operacionais de qualidade.

Descritores: Hanseníase; Vigilância; Busca de Comunicante; Prevenção \& Controle; Epidemiologia. 


\section{RESUMEN}

Objetivo: Caracterizar normas de abordaje de contactos intradomiciliarias(Cld) de casos de lepra residentes en el Norte de Brasil, de 20012012.Método: Estudio transversal y descriptivo en el estado de Rondônia. Incluidos Cld de casos de lepra diagnosticados/notificados en SINAN-Ministerio de Salud (MS), 2001-2012. Se aplicó instrumento semi estructurado a los Cld verificándose 6 intervenciones: examen dermatológico completo; examen neurológico completo; vacunación BCG; orientación para retorno a la unidad de salud; orientación sobre BCG y orientación para movilizar otros contactos. Resultados: Fueron incluidos 459 Cld. La no realización del examen dermatológico fue referida por 191 personas (41,6\%) y el neurológico, por 252 (54,9\%), 138(30,1\%) no tuvieron la BCG indicada y 122 (26,6\%) no recibieron orientaciones, 257 (56,0\%) no fueron orientados a retornar para nueva evaluación/seguimiento y $186(40,5 \%)$ no fueron orientados para movilización de otros contactos. Conclusión: A pesar de los indicadores favorables de cobertura de examen de Cld en el estado, el proceso de evaluación presenta normas que indican fallos operacionales de cualidad.

Descriptores: Lepra; Vigilancia; Busca de Comunicante; Prevención \& Control; Epidemiología.

\section{CORRESPONDING AUTHOR}

Helizandra Simoneti Bianchini Romanholo

E-mail: helizandrabianchini@msn.com

\section{INTRODUCTION}

Leprosy is a control neglected tropical disease with a prolonged evolution and high morbidity burden, it is considered a public health problem in various countries, including Bra$\mathrm{zil}^{(1)}$. It is a clinical dermato-neurological syndrome that presents a high potential to cause physical disability by evolving to deformities, besides its social and psychological impact ${ }^{(2-5)}$.

Despite the declining trend in the detection of new cases across the world, from 299,036 cases in 2005 to 210,758 in $2015^{(1)}$, leprosy remains at levels and with trends that are still far from under control(6). Of this total in $2015,74 \%$ of cases occurred in Asia and $13.6 \%$ in the Americas. Brazil is the second most affected country in the world in terms of absolute numbers, with 26,395 new cases and ranking first in the Americas ${ }^{(1)}$. In 2015, the overall detection coefficient in Brazil was 14.07 cases per 100,000 inhabitants, while in children under 15 it was 4.46 cases per 100,000 inhabitants ${ }^{(7)}$. These figures indicate a country with an endemic disease that is sustained at high levels $s^{(2,8-9)}$.

Although Brazil has also registered a reduction in the prevalence and detection coefficients of new cases of leprosy, the North, Northeast and Central-West regions maintain hyperendemic patterns, with clusters of important dynamic transmis$\operatorname{sion}^{(9-11)}$. Rondônia is considered to be one of the Brazilian states with the highest levels of endemicity. In 2013, the state had a general detection coefficient of 42.24 cases per 100,000 inhabitants and in children under 15 years, a detection coefficient of 12.33 cases for 100,000 inhabitants $^{(12)}$. Among the 52 municipalities in the state, the municipality of Cacoal accounts for a significant proportion of these cases, with a general detection coefficient above the state average of 45.42 cases per 100,000 inhabitants in 2013, and a detection coefficient in children under 15 years of 19.06 per 100,000 inhabitants ${ }^{(13)}$.

One of the key actions for the control of leprosy is the development of surveillance programs of intradomiciliary contacts, thereby guaranteeing adequate coverage and quality ${ }^{(8-9,14)}$. In fact, intradomiciliary contacts represent a population with a higher risk of disease than the general population due to the greater probability of exposure to the bacillus ${ }^{(15)}$. In Brazil (until February 2016, according to current guidelines at the time of the research), intradomiciliary contact was considered to include any person who resides or has lived with the leprosy patient in the last five years at the time of diagnosis ${ }^{(8)}$. Starting in March 2016, with the publication of the new guidelines for surveillance, care and elimination of leprosy, the Health Ministry considers household contact to be any person who resides or has resided with the leprosy patient, irrespective of the operational classification and duration. Furthermore, the surveillance is broadened to include social contact; defined as any person who lives or has lived in close and prolonged proximity, whether as a family member or not, with the untreated patient ${ }^{(16)}$.

With a focus on early detection and reduction of new cases of leprosy, the Ministry of Health ${ }^{(8,14)}$ proposed the epidemiological investigation of all intra-household contacts, including: dermatoneurological examination (DNE) of all intradomiciliary contacts with new cases of leprosy; a review of guidelines on the incubation period, transmission, early signs and symptoms of leprosy; and guidelines on the BCG (Bacille Calmette-Guérin) vaccine; in addition to guidelines for the application of vaccines.

Notwithstanding the importance of this set of strategic actions, it was observed that in Brazil that from 2002 to 2011 the proportion of contacts examined among the registered cases did not surpass $60 \%$. From 2012 to 2014, there was an increase to approximately $74 \%{ }^{(17)}$. This aspect is relevant, since it contributes to the unfinished agenda that the Country has to consider for effective control of the disease ${ }^{(18-19)}$.

In the state of Rondônia, it is noted that the proportion of contacts examined among those registered ranged from $72.9 \%$ in 2001 to $77.7 \%$ in $2013^{(12)}$. In turn, the municipality of Cacoal presented a $99.3 \%$ examination rate in 2013 , considered to be excellent coverage in the examination of contacts ${ }^{(13)}$.

It is recognized, however, that in addition to the achievement of satisfactory coverage levels in the assessment of intradomiciliary contacts, it is necessary that this evaluation be developed with a focus on integrality in health care and with sufficient quality for timely diagnosis and treatment ${ }^{(2,19-20)}$. This dimension has not been systematically addressed - neither by health services nor by research on the subject. In addition, there are few studies integrating the perspective of people affected by leprosy and their contacts ${ }^{(4)}$.

\section{OBJECTIVE}

To characterize the patterns in approaching intradomiciliary contacts of leprosy cases diagnosed from 2001 to 2012 in 
the municipality of Cacoal, Rondônia, from the perspective of these contacts.

\section{METHOD}

\section{Ethical aspects}

The project was approved by the Research Ethics Committee of the Federal University of Ceará (UFC-PROPESQ). The research was conducted in collaboration with the Municipal Health Department of Cacoal. Throughout the entire process, managers and health professionals from this municipality were involved, as well as teachers and students from local universities.

\section{Design, place of study and period}

A cross-sectional and descriptive study was carried out in the municipality of Cacoal, in the state of Rondônia, and conducted from April to October 2014. It is an integral part of the national multicenter project called IntegraHans-Norte/ Nordeste, coordinated by the Federal University of Ceará.

Cacoal is the fifth largest municipality in the state of Rondônia, with a population of 87,226 inhabitants in 2015, a population density of 20.72 inhabitants $/ \mathrm{km}^{2}$ and Municipal Human Development Index in 2010 of $0.718^{(21)}$. Population coverage by family health teams progressed from: $14.0 \%$ in 1999 ; to $23.3 \%$ in 2001 ; and then to $78.3 \%$ by $2015^{(22)}$.

\section{Study population}

Intradomiciliary contacts of people affected by leprosy diagnosed from 2001 to 2012 and living in the municipality of Cacoal, Rondônia. In this study, a household contact was considered to be any person who resides or has resided with the leprosy case in the last five years, at the time of diagnosis ${ }^{(12)}$, within the parameters of the Ministry of Health ${ }^{(8)}$.

Included in the study were those intra-household contacts whose reference cases (first case of leprosy reported in the same household within the study period) had previously authorized the approach by the researchers. Exclusion criteria were: intradomiciliary contacts not approached as a result of non-authorization by the reference cases; those who did not agree to participate in the research; and those that could not be located.

\section{Study protocol}

Data collection was carried out from April to October 2014. In a first step, to identify cases of leprosy, the database of the Information System of Notification Diseases (Sinan), provided by the Municipal Secretary Of Health of Cacoal, selecting only the cases residing in that municipality and when the leprosy was diagnosed in the period from 2001 to 2012.

The population base was defined as 908 cases of leprosy, from which 2,726 intradomiciliary contacts were registered in Sinan. In order to reach the intradomiciliary contacts, the addresses were updated using the database of the National Registry of Users of the Unified Health System (CadSUS), also made available by the city where the study is located.

The field activities were initiated with a visit to the homes of leprosy reference cases and after reading and signing the informed consent form to approach the contacts. For this activity, field researchers and professionals of the family health teams (including community health agents) were trained, with standardization of the work process in order to guarantee a technically appropriate ethical approach. The people affected by leprosy were asked to invite their intradomiciliary contacts to approach the family health unit or other defined social infrastructure located in their area of coverage.

The intradomiciliary contacts were interviewed by the researchers using a standardized structured instrument including variables related to gender, age, race, and questions related to the approach taken by health professionals at the time the reference leprosy case was diagnosed. The questions prioritized the recommendations in the Guidelines for Surveillance, Attention and Control of Leprosy $2010^{(8)}$.

In order to characterize the patterns for approaching the intradomiciliary contacts of leprosy cases, from the perspective of the user, the recommendations of Administrative Rule 3.125 of $2010^{(8)}$, in force when the research was conducted, were used as base, from which six main actions were identified in the surveillance process of intradomiciliary contacts: A) complete dermatological examination: inspection of the skin, in all body segments, for spots, plaques, nodules, papules and other signs and symptoms of leprosy; B) complete neurological examination: palpation of the main nerve trunks frequently affected and in the performance of tests to verify thermal, painful and tactile changes in lesions and suspicious areas; C) vaccination with BCG: individuals who were evaluated and after discarding signs and symptoms of leprosy followed the protocol stipulated by the Health Ministry regarding the application of BCG; D) orientation to return to the health unit: individuals are advised to return to the health unit for annual evaluation and/or if there were signs and symptoms of the disease; E) guidance on BCG vaccine: individuals are advised that the BCG vaccine is not a specific vaccine for immunization against leprosy; and F) orientation to seek other contacts: individuals are instructed to bring other intradomiciliary contacts to perform the contact exam.

\section{Analysis of results and statistics}

For the consolidation and descriptive analysis of the data, with absolute and relative frequency composition, the programs used were Epi-Info version 7.1.5 (Centers for Disease Control and Prevention, Atlanta, GA, USA) and Stata version 11.2 (Stata Corp LP, College Station, TX, USA).

\section{RESULTS}

A total of 313 cases of leprosy diagnosed during the study period and reported in Sinan were located and approached in the study. Regarding the intradomiciliary contacts of the reference cases, 2,267 were excluded due to the non-authorization to approach them or because they were residing in another municipality or had died. The final study population consisted of 459 contacts,

Of the $459(100 \%)$ household contacts interviewed, the mean age was 31.4 years (standard deviation 20.5), 270 (59.1\%) were female and the predominant race was brown, 268 (58\%). 
Table 1 refers to the procedures performed by the health team regarding the approach of contacts, during the period in which the reference case was in active registration. Of the 459 $(100 \%)$ contacts interviewed, $191(41.6 \%)$ reported not having the dermatological examination and 252 (54.9\%) did not undergo the neurological exam. Regarding the BCG vaccine, $321(69.9 \%)$ reported having been vaccinated. When asked if they were given guidance to return to the unit for reassessment, $257(56.0 \%)$ said they did not receive this guidance. Regarding guidance on the indication and schedule of the BCG vaccine, $337(73.4 \%)$ responded that they received this guidance, and $252(54.9 \%)$ reported that they were instructed to mobilize other intradomiciliary contacts for the evaluation.

Table 1 - Characterization of the approach to intradomiciliary contacts of leprosy cases by the health team, at the time diagnosis of the reference case was made, Cacoal, Rondônia, Brazil, 2014

\begin{tabular}{|c|c|c|}
\hline Contact approach variables & n (459) & $\%$ \\
\hline \multicolumn{3}{|l|}{ Dermatological Exam } \\
\hline Yes, complete (entire body) & 175 & 38.1 \\
\hline Yes, incomplete (partial body) & 56 & 12.2 \\
\hline Yes, not known if complete or partial & 12 & 2.6 \\
\hline Not performed & 191 & 41.6 \\
\hline Not known & 25 & 5.5 \\
\hline \multicolumn{3}{|c|}{ Neurological Exam } \\
\hline Yes, complete (face and upper and lower members) & 129 & 28.1 \\
\hline Yes, incomplete (face or upper or lower members) & 31 & 6.8 \\
\hline Yes, not known if complete or partial & 17 & 3.7 \\
\hline Not performed & 252 & 54.9 \\
\hline Not known & 30 & 6.5 \\
\hline \multicolumn{3}{|l|}{ Received BCG } \\
\hline Yes, 1 dose & 292 & 63.6 \\
\hline Yes, 2 doses & 23 & 5.0 \\
\hline Yes, did not remember how many doses & 6 & 1.3 \\
\hline Had cases of leprosy, but did not receive BCG & 101 & 22.0 \\
\hline Not known & 37 & 8.1 \\
\hline \multicolumn{3}{|l|}{ Counseled to return for future exam } \\
\hline Yes, return if there are signs or symptoms & 110 & 24.0 \\
\hline Yes, available after first exam & 26 & 5.7 \\
\hline Yes, did not know or remember when & 21 & 4.5 \\
\hline Yes, return for reevaluation scheduled & 13 & 2.8 \\
\hline No & 257 & 56.0 \\
\hline Not known /refused to answer & 32 & 7.0 \\
\hline \multicolumn{3}{|l|}{ Received advice on BCG } \\
\hline Yes & 337 & 73.4 \\
\hline No & 103 & 22.4 \\
\hline Not known /refused to answer & 19 & 4.2 \\
\hline \multicolumn{3}{|l|}{ Guidance to mobilize other contacts } \\
\hline Yes & 252 & 54.9 \\
\hline No & 186 & 40.5 \\
\hline Not known & 21 & 4.6 \\
\hline
\end{tabular}

Note: BCG - Bacilo de Calmette-Guérin vaccine.

When questioned about which health professional performed DNE, 139 (64.4\%) of the 216 (100\%) contacts who answered this question reported that they were evaluated by the nurse, followed by a technician or nursing assistant 60 $(37.8 \%)$, medical professional $8(3.7 \%)$, community health agent $1(0.5 \%)$, dental surgeon $1(0.5 \%)$ and dental assistant 1 $(0.5 \%)$. Six contacts did not remember the health professional who carried out the evaluation.

Among the intradomiciliary contacts who performed the dermatological and/or neurological examinations, 140 $(54.7 \%)$ stated that the main motivating factor was family mobilization and 98 (38.3\%) because they received counseling. Among those who reported difficulties, the lack of guidance was noted by 28 (58.3\%) people, followed by 7 (14.6\%) who reported incompatibility with the health service's schedule to perform this evaluation, as shown in Table 2.

Table 2 - Reasons that facilitated or impeded performance of the dermato-neurological examination of intradomiciliary contacts of leprosy cases, Cacoal, Rondônia, Brazil, 2014

\begin{tabular}{lcc}
\hline Factors that facilitated performing the DNE & $\mathbf{n ~ ( 2 5 6 )}$ & \% \\
\hline Mobilization by family & 140 & 54.7 \\
Was advised regarding this & 98 & 38.3 \\
Personal commitment to realize the exam & 15 & 5.9 \\
Compatibility of schedule with work obligations & 2 & 0.8 \\
Received a home visit & 1 & 0.4 \\
\hline Factors that impeded performing the DNE & $\mathbf{n}(\mathbf{4 8 )}$ & $\mathbf{2}$ \\
\hline Was not advised regarding this & 28 & 58.3 \\
Incompatibility of schedule with work obligations & 7 & 14.6 \\
Did not want to undergo exam & 4 & 8.3 \\
Family did not want to be involved & 2 & 4.2 \\
Transportation difficulties & 2 & 4.2 \\
Work & 1 & 2.1 \\
Others & 4 & 8.3 \\
\hline
\end{tabular}

Note: DNE - dermato-neurological exam.

\section{DISCUSSION}

The present study, in a hyperendemic area in the state of Rondônia, reveals that, in spite of widely accepted official indicators of global coverage of the examination of intradomiciliary contacts, the evaluation process presents operational failures in terms of the quality of these actions. It reinforces, therefore, the agenda not yet completed for leprosy control in Brazil ${ }^{(19)}$, indicating that the perspective of contacts is a significant element ${ }^{(4)}$.

The high loss of intradomiciliary contacts to be approached refers in large part to the temporal question between the evaluation action and the field work. Case cohorts were inserted in the municipality of Cacoal from 2001 to 2012, with evaluation in 2014, which explains aspects related to migration and deaths ${ }^{(23)}$. In addition, the refusals from leprosy reference cases may be associated with the strong disease-related stigma ${ }^{(3-4,19,24)}$. In the study population, there was a predominance of females, with average age in the economically productive range and brown ethnicity. This profile allows a preliminary inference for a lower weight of memory bias in this research. A study addressing lost 
contacts in Brazil corroborates the general aspects identified in this study ${ }^{(24)}$. Other studies reinforce the potential for follow-up of contacts, despite operational difficulties ${ }^{(25)}$.

The strategy to reduce the burden of leprosy and extent of disease control as a public health problem at the national level necessarily involves the qualified approach of leprosy case con$\operatorname{tacts}^{(2,4,15,20,25)}$. Appropriate investigation of the contacts is essential, since it contributes to a decisive interference in the transmission dynamics of the disease ${ }^{(20)}$. In addition, early diagnosis enables a positive effect on the natural history of the disease, especially at primary and secondary prevention levels $\mathrm{s}^{(2,18,20)}$, thereby reducing the chance of disability and deficiency, which ultimately has a strong social, economic and psychological impact( ${ }^{(3)}$.

Qualified dermato-neurological examination is essential for the detection of leprosy, since the diagnosis of this disease is eminently clinical ${ }^{(2,8-9,14,25)}$. However, it was observed in this study that most of the contacts interviewed reported not having undergone such a complete evaluation. It is valid to emphasize that in order to diagnose leprosy, it is necessary to carry out a thorough examination of the skin for spots, plaques, nodules, as well as alterations of thermal, pain and/or tactile sensitivity, as well as a thorough examination of peripheral nerve trunks by means of palpation, since leprosy may present as alterations in the skin and/or altered nerve trunk ${ }^{(2,8,14)}$.

Careful realization of this test is also necessary to provide the correct indication of BCG vaccine use according to the vaccination history ${ }^{(2,8,14)}$. It has been observed that the main action developed in contact surveillance is BCG vaccination, without the complete dermato-neurological examination. Only BCG vaccine is indicated when any suspicion of leprosy is excluded; If the patient presents signs and symptoms characteristic of the disease, it should be followed up with investigation and diagnosis, rather than administer $\mathrm{BCG}^{(2,8,14,24-25)}$.

Regarding the BCG vaccine, it was also observed that most of the contacts were advised on its indication. All contacts should receive guidance regarding the fact that the BCG vaccine is not specific for leprosy $\mathrm{y}^{(2,8,14)}$. In addition, it should be stressed that the fact receiving the vaccine will not prevent development of the disease itself, however it will reduce the chance of developing the most severe forms ${ }^{(20)}$. This fact reinforces the importance of longitudinal considerations in the care of households and families with expression of leprosy ${ }^{(2,14)}$.

In this last perspective, most of the respondents answered that they were not told to return to the health unit for a new evaluation. It is worth highlighting the relevance of evaluating the intrahousehold contacts annually for a period of 5 years, taking into account the incubation period of the disease, which is from 2 to 7 years, and that the intradomiciliary contacts have significant epidemiological importance, being considered at high risk and vulnerability compared to the general population ${ }^{(2,8,14-15,19-20)}$.

With an annual evaluation, the professional has the opportunity for early diagnosis of leprosy, thus avoiding deformities caused by the disease, as well as limiting the transmission dynamics $^{(4)}$. The orientation to mobilize other contacts to be evaluated has been verified with most contacts, which is important, since family involvement helps in the effectiveness of contact surveillance. However, considering the relevance of such action in addition to this passive surveillance, other more active strategies should be strengthened ${ }^{(14)}$.

Regarding the attribution of Basic Care/Family Health professionals in the control of leprosy, under the regulations of the Brazilian Ministry of Health, only the physician and the nurse are responsible for the dermato-neurological exam ${ }^{(2,8,14)}$. In this study, however, it was observed that although most of the contacts were evaluated by the nurse and a minority by doctors, it was also performed by other professionals considered not qualified to perform this function. Each health professional must recognize and assume his/her role in disease prevention, surveillance and control $^{(2,8,14)}$. The lack of quality identified by the present research relative to the examination of contacts may be directly related to this scenario.

Among the factors that facilitated the examination, family involvement and the guidance given to cases of leprosy on the importance of performing the dermato-neurological exam demonstrate the importance of a more active involvement by the families of those affected by the disease. On the other hand, corroborating the previous questions, most of the contacts that reported difficulties in carrying out the examination reinforced as a main factor the lack of orientation. These data reiterate the need for more informed actions in health education, especially in basic health care ${ }^{(2,8,14)}$. One of the justifications for this aspect may be associated with the low coverage of the Family Health Strategy in the municipality of Cacoal during the period considered in this study, which was below $35 \%$ until the first half of 2014 , with no more than eight family health teams ${ }^{(22)}$. However, the current scenario since mid2014 of population coverage by the family health teams is approximately $78 \%{ }^{(22)}$, with 18 teams, and may increase still further in the future. In addition to this is the great potential of the Family Health Support Unit team incorporated into the health network of the municipality, which can qualify the actions through matriculation with the Family Health Strategy.

\section{Limitations of the study}

The present study presents limitations related, initially, to the secondary reference database with addresses for the identification of intradomiciliary contacts with the reference cases (Sinan). However, the option to insert the CadSUS database, which is more up-to-date in terms of the addresses, minimized these problems, hence valorizing the use of a population database. Another aspect to be considered refers to memory and cohort biases: the study integrated people diagnosed with an elapsed time of 2 to 13 years for the interview regarding their intradomiciliary contacts. In addition to the migration and death aspects, the refusal of reference cases to authorize the approach of their intradomiciliary contacts may be related to issues of stigma and prejudice that are still present, even in historically hyperendemic areas such as in this study.

\section{Contributions to the area of nursing, health or public policy}

The importance of this study is underscored considering its unusual approach and the relevant questions to qualify the surveillance of contacts of leprosy in Brazil; the present study also presented data showing the fragility of the service 
regarding the examination of intradomiciliary leprosy contacts. Therefore, new perspectives are opened for studies on the theme, beyond the scenario of the state of Rondônia.

\section{CONCLUSION}

The process for evaluation of intradomiciliary contacts in the reality of the municipality of Cacoal, from the perspective of the user, presents operational failures that translate clear standards of insufficiency in the quality of these actions, even though they are fundamental for the control of leprosy. Poor quality was observed in the incomplete nature of the dermatological clinical evaluation and especially the neurological evaluation, which together are essential for the diagnosis of the disease, as well as indication for the BCG vaccine without considering the clinical evaluation. The lack of guidance by health professionals regarding the BCG vaccine, the return to the health unit and orientation to mobilize other contacts is also noteworthy.

Finally, we reiterate the importance of reinforcing intradomiciliary contact surveillance actions, based on the guarantee of examination coverage, but above all on the quality of execution of this approach, which is essential for the control of leprosy as a public health problem.

\section{FUNDING}

Financial support: This work is part of the multicenter national study "IntegraHans Norte e Nordeste", which includes the states of Rondônia, Tocantins and Bahia, under the coordination of the Federal University of Ceará and financed by the National Council of Scientific Development (CNPq), process number 404505/2012-0 and by NHR Brazil (Netherlands Hanseniasis Relief - Brazil, branch/representative office of NLR -Netherlands Leprosy Relief).

\section{ACKNOWLEDGEMENTS}

City Hall of Cacoal, State Government of Rondônia, Faculty of Biomedical Sciences of Cacoal (FACIMED), Netherlands Hanseniasis Relief - Brazil (NHR Brazil), Federal University of Ceará (UFC) and National Council for Scientific and Technological Development (CNPQ).

\section{REFERENCES}

1. World Health Organization. Department of Control Neglected Tropical Diseases. Global leprosy update, 2015: time for action, accountability and inclusion. WER [Internet]. 2016 [cited 2017 Mar 01];91(35):405-20. Available from: http://www.who.int/lep/ resources/who_wer9135/en/

2. Brasil. Ministério da Saúde. Secretaria de Atenção à Saúde. Departamento de Atenção Básica. Vigilância em Saúde: Dengue, Esquistossomose, Hanseníase, Malária, Tracoma e Tuberculose. Série A. Normas e Manuais Técnicos - Cadernos de Atenção Básica, n. 21[Internet]. Brasília: Ministério da Saúde. 2008 [cited 2016 Jul 03]. 199 p. Available from: http://dab.saude.gov.br/ docs/publicacoes/cadernos_ab/abcad21.pdf

3. Barbosa JC, Ramos Jr AN, Alencar MJ, Castro CG. Pós-alta em Hanseníase no Ceará: limitação da atividade funcional, consciência de risco e participação social. Rev Bras Enferm [Internet]. 2008 [cited 2016 Jul 13];61(spec):727-33. Available from: http://www. scielo.br/pdf/reben/v61nspe/a12v61esp.pdf

4. Ramos Jr AN, Oliveira MLW, Barbosa JC, Kerr LRS, Alencar CHM, Heukelbach J. Pesquisas em hanseníase: Contextos e agendas. In. Universidade de Brasília-UnB. Hanseníase: avanços e desafios. Brasília: NESPROM[Internet]. 2014 [cited 2016 Jul 13];455-90. Available from: http://pesquisa.bvs.br/brasil/resource/pt/ses-30692

5. Van Brakel WH, Sihombing B, Djarir H, Beise K, Kusumawardhani L, Yulihane R, et al. Disability in people affected by leprosy: the role of impairment, activity, social participation, stigma and discrimination. Glob Health Action[Internet]. 2012 [cited 2016 Jul 03];5. Available from: https://www.ncbi.nlm.nih.gov/pubmed/22826694

6. Schreuder PA, Noto S, Richardus JH. Epidemiologic trends of leprosy for the 21 st century. Clin Dermatol[Internet]. 2016 [cited 2016 Jan 31];34(1):24-31. Available from: http://www.sciencedirect.com/science/article/pii/S0738081X15001996

7. Brasil. Ministério da Saúde. Secretaria de Vigilância em Saúde. Sistema de Informação de Agravos de Notificação. Taxas de detecção geral e em menores de 15 anos de hanseníase no Brasil, 1994 a 2015[Internet]. Portal da Saúde. 31 Maio 2016 [cited 2017 Feb 20]. Available from: http://portalarquivos.saude.gov.br/images/pdf/2016/julho/07/Taxas-de-detec--o-geral-e-em-menores-de-15-anos-dehansen-ase-94-a-2015.pdf

8. Brasil. Ministério da Saúde. Gabinete do Ministro. Portaria n 3125, de 7 de outubro de 2010. Aprova as diretrizes para vigilância, atenção e controle da hanseníase. Diário Oficial da República Federativa do Brasil, Poder Executivo[Internet]. Brasília, DF. 15 Out. 2010 [cited 2016 Jul 13]; Seção 1, p.55. Available from: http://www.anvisa.gov.br/hotsite/talidomida/legis/portaria_n_3125_ hanseniase 2010.pdf

9. Brasil. Ministério da Saúde. Plano integrado de ações estratégicas de eliminação da hanseníase, filariose, esquistossomose e oncocercose como problema de saúde pública, tracoma como causa de cegueira e controle das geohelmintíases: plano de ação 2011-2015[Internet]. Brasília-DF: Ministério da Saúde. 2012 [cited 2016 Jul 23]. Available from: http://bvsms.saude.gov.br/bvs/ publicacoes/plano_integrado_acoes_estrategicas_2011_2015.pdf

10. Penna ML, Grossi MA, Penna GO. Country profile: leprosy in Brazil. Lepr Rev[Internet]. 2013 [cited 2016 Jul 13];84:308-15. 
Available from: http://www.lepra.org.uk/platforms/lepra/files/lr/Dec13/Lep308-315.pdf

11. Nery JS, Pereira SM, Rasella D, Penna ML, Aquino R, Rodrigues LC, et al. Effect of the Brazilian conditional cash transfer and primary health care programs on the new case detection rate of leprosy. PLos Negl Trop Dis[Internet]. 2014 [cited 2016 Jul 23];8(11):e3357. Available from: http://journals.plos.org/plosntds/article?id=10.1371/journal.pntd.0003357

12. Rondônia. Agência de Vigilância em Saúde de Rondônia. Boletim epidemiológico de hanseníase - 2014, Estado de Rondônia, Brasil. Governo do Estado de Rondônia: Porto Velho, Rondônia, 2014, 44 p.

13. Cacoal. Secretaria Municipal de Saúde. Síntese de indicadores epidemiológicos e operacionais Município de Cacoal - 2014, Estado de Rondônia, Brasil. Prefeitura Municipal de Cacoal: Cacoal, 2014, 31 p.

14. Brasil. Ministério da Saúde. Secretaria de Vigilância em Saúde. Guia de vigilância em saúde[Internet]. Brasília: Ministério da Saúde. 2014 [cited 2016 Jun 04]. 812 p. Available from: http://portalsaude.saude.gov.br/images/pdf/2014/novembro/27/guiavigilancia-saude-linkado-27-11-14.pdf

15. Bratschi MW, Steinmann P, Wickenden A, Gillis TP. Current knowledge on Mycobacterium leprae transmission: a systematic literature review. Lepr Rev [Internet]. 2015 [cited 2016 Jun 03];86:142-55. Available from: https://www.researchgate.net/ profile/Peter_Steinmann/publication/281030220_Current_knowledge_on_Mycobacterium_leprae_transmission_A_systematic_ literature_review/links/55d1ace908ae502646aa5d̄c0.pdf

16. Brasil. Ministério da Saúde. Secretaria de Vigilância em Saúde. Departamento de Vigilância das Doenças Transmissíveis. Diretrizes para vigilância, atenção e eliminação da Hanseníase como problema de saúde pública: manual técnico-operacional[Internet]. Brasília: Ministério da Saúde. 2016 [cited 2016 Jul 03]; 58 p. Available from: http://portalarquivos.saude.gov.br/images/pdf/2016/ fevereiro/04/diretrizes-eliminacao-hanseniase-4fev16-web.pdf

17. Brasil. Ministério da Saúde. Secretaria de Vigilância em Saúde. Indicadores epidemiológicos e operacionais de hanseníase, Brasil 2000-2014[Internet]. Portal da Saúde. 31 Maio 2016 [cited 2017 Feb 28]. Available from: http://portalsaude.saude.gov.br/images/ pdf/2015/outubro/29/S--rie-Hist--rica-Hansen--ase-2000---2014.pdf

18. Alencar CH, Barbosa JC, Ramos Jr AN, Alencar MJ, Pontes RJ, Castro CG, Heukelbach J. Hanseníase no município de Fortaleza, CE, Brasil: aspectos epidemiológicos e operacionais em menores de 15 anos (1995-2006). Rev Bras Enferm[Internet]. 2008 [cited 2016 Jun 23];61(spec):694-700. Available from: http://www.producao.usp.br/handle/BDPI/12890

19. Alencar CH, Ramos Jr AN, Barbosa JC, Kerr LR, De Oliveira ML, Heukelbach J. Persisting leprosy transmission despite increased control measures in a endemic cluster in Brazil: the unfinished agenda. Lepr Rev [Internet]. 2012 [cited 2016 Jul 03];83(4):344-53. Available from: https://www.ncbi.nlm.nih.gov/pubmed/23614252

20. Smith WC, Aerts A. Role of contact tracing and prevention strategies in the interruption of leprosy transmission. Lepr Rev [Internet]. 2014 [cited 2016 Jul 13];85(1):2-17. Available from: https://www.ncbi.nlm.nih.gov/pubmed/24974438

21. Brasil. Instituto Brasileiro de Geografia e Estatística. Cidades, Rondônia-Cacoal [Internet]. 2015 [cited 2016 Jul 03]. Available from: http://cidades.ibge.gov.br/xtras/perfil.php?codmun $=110004$

22. Brasil. Ministério da Saúde. Secretaria de Atenção à Saúde. Departamento de Atenção Básica. Histórico de Cobertura da Saúde da Família[Internet]. Portal da Saúde. 2015 [cited 2016 Sep 01]. Available from: http://dab.saude.gov.br/portaldab/ historico_cobertura_sf.php

23. Murto C, Ariza L, Alencar CH, Chichava OA, Oliveira AR, Kaplan C, Silva LF, Heukelbach J. Migration among individuals with leprosy: a population-based study in central Brazil. Cad Saude Publica[Internet]. 2014 [cited 2016 Jun 13];30(3):487-501. Available from: http://www.scielosp.org/pdf/csp/v30n3/0102-311X-csp-30-3-0487.pdf

24. Vieira CSCA, Soares MT, Ribeiro CTSX, Silva LFG. Avaliação e controle de contatos faltosos de doentes com hanseníase. Rev Bras Enferm[Internet]. 2008 [cited 2016 Jun 22];61(spe):682-88. Available from: http://www.scielo.br/pdf/reben/v61nspe/a05v61esp.pdf

25. Durães SMB, Guedes LS, Cunha MD, Magnanini MMF, Oliveira MLW. Estudo epidemiológico de 107 focos familiares de hanseníase no município de Duque de Caxias - Rio de Janeiro, Brasil. An Bras Dermatol[Internet]. 2010 [cited 2016 Jun 22];85(3):339-45. Available from: http://www.scielo.br/pdf/abd/v85n3/en_a07v85n3.pdf 